\title{
SORONG SERAH (STUDI ANALITIK PERUBAHAN KEPATUHAN BUDAYA)
}

\section{Safruddin}

Pendidikan Sejarah, Universitas Muhammadiyah Mataram, Af.an11@yahoo.com

\section{INFO ARTIKEL}

\section{RiwayatArtikel:}

Diterima: 03-11-2016

Disetujui: 05-12-2016

\section{Kata Kunci:}

1. PerubahanKepatuhan

2. SorongSerah

\begin{abstract}
ABSTRAK
Abstrak:

Penelitian ini bertujuan untuk meneliti dan mengungkapkan secara deskriftif analitik fenomenologis perubahan kepatuhan dalam budaya Sorong Serah pada masyarakat di Kecamatan Selong yang dipengaruhi oleh beberapa variable seperti pendidikan, pemahaman agama dan globalisasi sebagai variabel yang merubahnya. Pendekatan yang digunakan yaitu kualitatif dengan menggunakan metode fenomenologis dengan teknik pengumpulan data melalui Observasi, Wawancara dan Dokumentasi. Hasil penelitian diantaranya: Dalam aspek pendidikan, perubahan tersebut secara umum disebabkan oleh faktor yang determinan yaitu faktor kebahasaan yang digunakan dalam prosesi Sorong serah. Dalam aspek pengetahuan agama, banyak memberikan penanaman dan pembiasaan dalam masyarakat di Kecamatan Selong untuk kembali kepada ajaran yang di ajarkan dalam agama melalui proses pendidikannya. Dalam aspek globalisasi, adanya pemikiran masyarakat untuk lebih menyederhanakan delapan step proses adat merariq. Dimaklumi bahwa prosesi pernikahan baik dalam proses sebelum dan sesudah akad nikah membutuhkan kesibukan yang cukup banyak untuk semua keluarga, maka untuk mengurangi itu semua maka penyederhanaan proses merariq menjadi sebuah keniscayaan.

This study aims to examine and reveal descriptively the phenomenological analysis of compliance change within the Sorong Serah culture in the community in Kecamatan Selong that is influenced by some variables such as education, religious understanding and globalization as the variables that change it. The approach used is qualitative by using phenomenological method with data collection technique through Observation, Interview and Documentation. The results of research include: In the aspect of education, the change is generally caused by a determinant factor is the language factor used in the procession Sorong handing. In the aspect of religious knowledge, many provide planting and habituation in the community in Kecamatan Selong to return to the teachings that are taught in religion through the process of education. In the aspect of globalization, the thought of the community to further simplify the eight steps of customary merariq process. It is understandable that the procession of marriage both in the process before and after the marriage ceremony requires a lot of busyness for all families, so to reduce it all then simplifying the process merariq be a necessity.
\end{abstract}

\section{A. LATAR BELAKANG}

Pada masyarakat suku Sasak di pulau Lombok, mereka memiliki tradisi yang khas untuk memulai prosesi pernikahan secara adat. Berbeda dengan umumnya tradisi memulai pernikahan yang dilaksanakan masyarakat Muslim, yaitu dengan khitbah atau melamar, masyarakat Muslim Sasak pada umumnya menggunakan tradisi merariq (kawin lari). Makna merariq (kawin lari) pada masyarakat suku Sasak berbeda dengan makna perkawinan yang ada pada masyarakat Bugis yang dikenal dengan istilah Silariang.Dimana pada masyarakat Bugis, Silariang dianggap sebagai sesuatu yang melanggar norma adat atau dalam nilai budaya bugis termasuk dalam pelanggaran terhadap nilai Sirri. Dan para pelakunya biasanya harus membayar atas dasar kesalahan tersebut dengan nyawa/dibunuh. Sementara konsep perkawinan (merariq) menurut suku Sasak yaitu menikah dengan cara mencuri atau melarikan gadis yang akan dinikahinya, dimana mencuri anak gadis orang lain untuk dinikahi dianggap lebih kesatria dibandingkan meminta kepada orang tuanya.

Merariq istilah bahasa setempat untuk menyebutkan proses pernikahan dengan cara dicuri, caranya cukup sederhana jika keduanya saling menyukai dan tidak ada paksaan dari pihak lain, mencuri gadis dengan cara Merariq itu lebih terhormat dibandingkan meminta pada orang tuanya, (Payasan, L. 2004 : 3)

Dalam bahasa Indonesia Merariq sama artinya dengan perkawinan. Dimana Perkawinan adalah suatu 
peristiwa sosial penting yang harus dilalui oleh setiap orang. Melihat dari realita yang terjadi, Merariq ini adalah hal yang di anggap suatu kebenaran oleh masyarakat suku Sasak, karena ini merupakan budaya yang ditinggalkan oleh nenek moyang dan dijadikan sebagai suatu adat istiadat. Merariq atau membawa lari anak gadis orang untuk dinikahi ini terjadi dari masa kemasa, karena budaya merariq adalah sangat kental dipengaruhi oleh budaya Bali. Dikatakan dipengaruhi oleh budaya Bali karna Lombok pernah dikuasai oleh kerajaan Karang Asem Bali pada saat itu. Berdasarkan fakta sejarah, kerajaan Karang Asem Bali berhasil menguasai kerajaan yang ada di pulau Lombok tepatnya sekitar abad 17 masehi. Jadi sedikit tidaknya sebagai penguasa (kerajaan Bali) berupaya untuk memasukkan pengaruhnya seluas mungkin atas daerah jajahannya (kerajaan Lombok) sampai kepada pengaruh kebudayaan, bahkan jika mungkin sampai kepada keyakinan rakyat yang dikuasainya.

Payasan, Lalu (2004 : 3) menyinggung sekilas masalah kebahasaan. Kata merariq menurutnya berasal dari kata $m e+r a+r i q$ atau memper + arik yang dalam bahasa Indonesianya berarti memperadik atau memperistri. Adapun prosesi merariq/ perkawinan dalam masyarakat Sasak adalah sebagai berikut:

1. Mesejati : mempermaklumkan kepada pemerintah desa/perangkat desa dimana calon mempelai wanita dan keluarganya tinggal (dilaksanakan oleh keluarga pihak mempelai laki-laki), bahwa si A memang betul menikah dengan si B (bahwa si A memang betul dilarikan oleh di B).

2. Selabar : menyampaikan secara langsung kepada pihak keluarga wanita bahwa si A (anak gadis mereka) memang betul merariq atau dilarikan oleh si B. Diikuti dengan tahapan menyelesaikan secara lengkap identitas keluarga pihak laki-laki.

3. Bait Wali : sekelompok orang yang diutus oleh pihak keluarga laki-laki untuk mengambil atau menjemput wali dari pihak wanita agar segera menikahkan putera-puteri mereka (karena umumnya upacara akad nikah dilaksanakan di tempat tinggal keluarga pihak laki-laki).

4. Rebak Pucuk: menyampaikan pesan oleh pengemban amanah untuk menanyakan apakah keluarga dari pihak wanita siap untuk menerimanya.

5. Bait Janji : menindaklanjuti proses di atas bahwa pihak laki-laki mendatangi pihak perempuan untuk menentukan hari pelaksanaan upacara adat Sorong serah sekaligus membicarakan hal-hal yang terkait dengan persyaratan-persyaratan yang akan melengkapi upacara adat tersebut.

6. Sorong serah: upacara ini sekaligus sebagai upacara puncak adat untuk mengukuhkan secara syah perihal perkawinan kedua mempelai. Dalam ritual inilah dipersiapkan beberapa perangkat adat seperti:

a. Pisolo: sekelompok orang yang diutus oleh seorang Pembayun untuk menanyakan kepada sekelompok Penampi (Penerima) dari pihak perempuan.

b. Pembayun: pengemban amanat yang dipercayakan oleh keluarga pihak laki-laki untuk menyelesaikan prosesi adat Sorong serah bersama dengan perangkat desa, para tokoh agama, tokoh masyarakat, dengan membawa properti yang merupakan lambang adat Sasak antara lain : aji, lampak lemah, pemegat, mesesirah, olen, semprong, ceraken, dan lain-lain.

7. Nyongkolan : keluarga pihak laki-laki dan kedua mempelai mengunjungi pihak perempuan dan keluarganya dengan pakaian adat lengkap serta iringan gamelan dan gendang beleq (alat musik tradisional Sasak).

8. Balik Lampak, merupakan tradisi berkunjung ke pihak laki-laki sebagai silaturrahmi balasan dari pihak perempuan.

Dalam hal penyelesain prosesi adat perkawinan (istilah suku Sasak disebut merariq) pada masyarakat suku Sasak mengenal apa yang dinamakan dengan Sorong serah. Esensi dari nilai dalam adat Sorong serah adalah budaya lokal suku Sasak dalam menuntaskan seluruh acara perkawinan adat suku Sasak (merariq).

MenurutAzhar Sorong serah adalah serah terima lambang adat". Berdasarkan pendapat ahli tersebut dapat dijelaskan bahwa Sorong serah adalah proses serah terima lambang adat. Penyerahan lambang adat ini adalah keluarga pengantin laki-laki dan penerima adalah keluarga pihak pengantin perempuan. Sorong serah merupakan salah satu 
rangkaian penyelesaian upacara perkawinan suku Sasak(Azhar, $1987: 45)$.

Sesungguhnya Sorong serahmerupakan salah satu karya sastra berupa nilai-nilai dalam perilaku masyarakat. Adat budaya Sorong serah tersebut sangat tinggi nilainya dan penting untuk dikaji serta diketahui makna yang terkandung dalam bahasa simbol oleh masyarakat, diikuti dan diteladani sehingga berguna bagi kehidupan masyarakat Sasak.

Sorong serah di kalangan masyarakat Sasak adalah refleksi diri dari nilai keluarga yang merupakan puncak tertinggi dari sebuah upacara perkawinan pada masyarakat suku Sasak. Nilai yang menurut sebagian besar masyarakatnya adalah sebuah harga mati untuk nilai suatu keluarga dalam masyarakatnya. Akan sangat malu bila ada keluarga yang tidak sempurna dalam menjalankan prosesi perkawinan tanpa melalui prosesi adat Sorong serah tersebut. Keadaan dan kondisi ini di beberapa kawasan di wilayah Lombok masih tetap berusaha dilestarikan keberadaannya. Menurut mereka Sorong serah adalah bagian dari budaya leluhur yang harus tetap di lestarikan keberadaannya sebagai sebuah warisan akan nilai budaya. Namun tidak sedikit juga masyarakat Sasak, yang sudah tidak lagi menggunakan atau malaksanakan prosesi adat Sorong serah tersebut.

Fenomena memudarnya nilai Sorong serah tersebut lahir dengan berbagai alasan terutama di kawasan yang sudah banyak tersentuh oleh budaya luar baik itu berupa pengaruh tingkat pendidikan, pemahaman terhadap nilai-nilai agama yang semakin kuat atau bahkan dikarenakan oleh modernisasi dan globalisasi yang melanda seluruh aspek kehidupan manusia dewasa ini

Dalam segi pendidikan, dengan semakin berkembangnya tingkat pendidikan yang dialami oleh masyarakat Sasak di Kecamatan Selong, memberikan dampak terhadap berkembang pesatnya proses pemahaman dan rasionalitas manusianya dalam memahami dan memaknai suatu nilai yang akan mereka jalankan. Termasuk dalam hal pelaksanaan perkawinan (merariq) apakah dengan melaksanakan Sorong serah atau tidak. Dengan pertimbangan rasionalitas secara ekonomi dalam pelaksanaan Sorong serah yang menuntut para pelaksananya untuk mengelurkan pendanaan yang tidak sedikit, serta pemahaman makna perkawinan (merariq) secara hukum Negara dan pemahaman terhadap nilai agama juga merupakan acuan dasar yang kemudian memberikan pijakan dalam penentuan apakah Sorong serah perlu dilaksanakan dalam prosesi perkawinan (merariq). Dalam bahasa yang lain masyarakat semakin terdidik untuk memilih dan memilih hal mana yang seharusnya mereka jalankan atau tidak.

Dari segi pemahaman nilai agama yang dimiliki oleh masyarakat di kecamatan Selong dewasa ini tergolong semakin maju, hal tersebut ditandai dengan kondisi sosial dari masyarakat dalam melaksanakan kegiatan keagamaan mereka, serta dalam hal melaksanakan sesuatu hal dalam korelasinya yang bersinggungan dengan asas nilai keagamaan. Sebuah pengkondisian dimana masyarakat kini sudah lebih realistis dalam memandang dan memaknai setiap bentuk pengaruh dari tradisi lama. Hal semacam itu ditunjang dengan keberadaaan yayasan pendidikan yang ada di kecamatan Selong. Yayasan yang dimaksud ialah sebuah yayasan pendidikan yang dalam prakteknya lembaga pendidikan yang berasaskan nilai Islam. Dalam kehidupan masyarakat di kecamatan Selong yayasan tersebut telah sangat banyak merubah konsep masyarakat terutama dalam hal pendidikan keagamaan. Sehingga dalam prakteknya masyarakat di kecamatan Selong dalam hal pelaksanaan perkawinannya sudah tidak lagi menjalankan setiap aturan yang tidak berkorelasi dengan nilai agama Islam. Dalam acara adat perkawinan suku sasak di kecamatan Selong, hal yang kemudian tidak lagi dijalankan oleh masyarakat ialah prosesi adat Sorong serah. Karena dianggap tidak terlalu penting untuk dijalankan karena bagian dari warisan penjajah Bali (hindu) sewaktu berkuasa di Lombok.

Serta pengaruh yang tidak bisa terelakkan ialah arus globalisasi yang merubah pola pikir manusia terutama anak muda yang sangat cepat menerima perubahan yang dibawa oleh proses globalisasi ini. Perkembangan media massa, internet, media sosial dan sebagainya telah memberikan nuansa dan kesan baru dalam pola berfikir masyarakat di kecamatan Selong. Termasuk di dalamnya ialah media informasi yang berdatangan dari luar mereka, informasi tentang 
keberagaman dalam tata cara hidup. Dalam aplikasinya kemudian masyarakat di kecamatan Selong lebih terbiasa berfikir secara lebih praktis dan ekonomis dalam memandang dan memaknai sesuatu. Termasuk dalam hal pelaksanaan prosesi perkawinan adat suu sasak di kecamatan Selong, mereka lebih berfikir bagaimana hidup lebih praktis dan ekonomis. Pola pikir semacam itulah yang kemudian melemahkan posisi nilai adat/ norma bahkan penghilangan adat Sorong serahdalam praktek perkawinan adatnya.

Sorong serah sebagai tradisi yang disampaikan secara pragmatik dan turun temurun sudah dianggap kuno atau ketinggalan zaman untuk dilestarikan, atau dijadikan hiburan, terutama di kalangan generasi muda. Dapat disaksikan adat Sorong serah ini pada kenyataaan bahwa motivasi untuk menekuni dan melestarikan budaya Sorong serah pada kalangan muda dalam masyarakat Suku Sasak sudah berkurang. Kaum muda sudah tergiur oleh kemajuan seni internasional yang belum tentu sesuai dengan budaya bangsa Indonesia. Dan kondisi ini lebih diperparah lagi dengan kenyataan dimana tidak sedikit generasi tua pun masih banyak yang tidak tahu atau memahami arti dan makna dari Sorong serah itu sendiri. Atau dengan kata lain dalam masyarakat Sasak itu sendiri sudah mulai terjadi proses pelemahan/ pemudaran terhadap nilai kepatuhan terkait dengan nilai kearifan budaya sendiri yakni Sorong serah. Atau dengan kata lain proses enkulturasi budaya yang tidak berjalan sebagaimana mestinya.

Fenomena diatas inilah yang di maknai oleh peneliti sebagai bentuk dari ketidakpatuhan dalam budaya Sorong serah. Menurut kamus besar bahasa indonesia kepatuhan berasal dari kata patuh yang berarti sukamenurut (perintah dan sebagainya); taat (kepada perintah, aturan, dan sebagainya. Sedangkan kepatuhan memiliki arti sifatpatuh; ketaatan. (Kamus Umum Bahasa Indonesia, 1995 : 1962)

Apabila hal ini dibiarkan berlarut-larut maka budaya ini lambat laun, perlahan namun pasti akan terkikis atau akan punah di daerah Lombok dan juga kehilangan potensi budaya bangsa. Dari fenomena di atas, maka peneliti termotivasi atau tertarik mengangkat masalah Sorong serah sebagai sebuah Studi Analitik
Perubahan Kepatuhan Budaya pada masyarakat Suku Sasak.

Penelitian ini memfokuskan pada bagian "Sorong serah sebagai Studi Analitik tentang Perubahan Kepatuhan Budaya" pada masyarakat Suku Sasak, dengan beberapa aspek menjadi faktor determinan yang menjadi faktor yang mempengaruhinya yakni faktor pendidikan; pemahaman agama dan globalisasi. Mengingat budaya Sorong serah adalah hukum adat suku Sasak yang sangat kental dilihat dari kearifan budaya setempat. Dan lokasi dari fokus kajian dalam penelitian ini adalah pada masyarakat yang sudah tidak lagi menjalankan prosesi adat Sorong serah yakni di Kecamatan Selong Kabupaten Lombok Timur Nusa Tenggara Barat.

\section{B. METODE PENELITIAN}

Adapun jenis dan pendekatan penelitian yang digunakan dalam penelitian ini adalah pendekatan kualitatif murni. Karena penelitiannya dilakukan pada kondisi yang alamiah (Natural Setting); disebut juga sebagai metode etnographi, karena pada awalnya metode ini lebih banyak digunakan untuk penelitian dengan bidang antropologi budaya; disebut sebagai metode kualitatif, karena data yang terkumpul dan analisa lebih bersifat kualitaif (Sugiono, $2012:$ 1).

Sedangkan metode yang akan digunakan dalam penelitian ini adalah metode Fenomenoligis.Ada pun Tehnik pengumpulan data yang digunakan dalam penelitian ini adalah sebagai berikut:Observasi, Wawancara dan Dokumentasi. Sedangkan tehnik analisis data yang digunakan dalam penelitian ini adalah Reduksi Data, Penyajian Data, Verivication (penarikankesimpulan).

\section{HASIL DAN PEMBAHASAN}

Faktor pendidikan di kecamatan Selong mampu membentuk perubahan kepatuhan masyarakat dalam hal pelaksanaan Sorong serah, hal yang terindikasi sebagai bagian dari faktor pendidikan ialah dikarenakan adanya usaha/ upaya dari masyarakat/ individu dalam proses belajar mencari tahu tentang kebenaran budaya yang selama ini mereka pakai/ gunakan. Sebuah fenomena dari cuplikan dalam kehidupan masyarakat di kecamatan 
Selong dewasa ini ialah mulai tumbuh dan berkembangnya animo dan antusias dari masyarakat dalam mencari tahu tentang sisi kebenaran dari budaya yang kini banyak dipertanyakan asal usulnya oleh warga masyarakat di kecamatan Selong. Hal ini yang kemudian dalam proses perjalanan pencaritahuan tentang jati diri budaya yang dimiliki oleh masyarakat suku Sasak ternyata adalah warisan dari penjajah hindu bali, kenyataan tersebut telah banyak merubah pola pikir dalam masyarakat di kecamatan Selong dalam memahami dan memaknai budaya yang ada dewasa ini. Termasuk kemudian budaya dalam tradisi perkawinan adat sasak yakni Sorong serah yang kemudian tidak lagi dijalankan oleh masyarakat di kecamatan Selong dewasa ini. Atas dasar bukan asli budaya dari leluhur suku Sasak.

Hal lain yang termasuk kedalam proses pendidikan dalam perubahan kepatuhan masyarakat ialah dikarenakan dari segi kebahasaan yang digunakan dalam prosesi Sorong serah yang terlampaui sulit untuk dipelajari oleh masyarakat di kecamatan Selong dewasa ini. Sehingga hal tersebut merupakan bagian dari faktor pendidikan yang telah merubah masyarakat di kecamatan Selong sehingga tidak patuh dalam menjalankan prosesi adat Sorong serah. Masyarakat di kecamatan Selong dewasa ini sangat sulit sekali memahami bahasa yang digunakan dalam prosesi adat Sorong serah tersebut dikarenakan bahasa yang digunakan ialah bahasa yang bersumber dari bahasa jawa kuno (hanacaraka). Sehingga hal keterbatasan dalam hal penguasaan bahasa tersebut yang juga ikut kedalam faktor kebahasaan dalam merubah ketidakpatuhan masyarakat di kecamatan Selong dalam hal menjalankan prosesi adat Sorong serah.

Dengan keberadaan dari lembaga pendidikan YPH PPD NW yang banyak tersebar hampir di seluruh wilayah kabupaten Lombok Timur memberikan banyak penanaman dan pembiasaan dalam masyarakat di Kecamatan Selong untuk kembali kepada ajaran yang di ajarkan dalam agama melalui proses pendidikannya.

Kemudian hal lain yang muncul kepermukaan dalam proses perubahan kepatuhan masyarakat pada ritual Sorong serah ialah terjadinya peringkasan dalam prosesi perkawinan masyarakat Sasak di Kecamatan Selong sebagai sebuah manifestasi dari pemahaman atas interpretasi masyarakat terhadap apa yang mereka dapat selama menuntut ilmu agama.

\section{SIMPULAN DAN SARAN}

Berdasarkan data hasil penelitian, maka dapat disimpulkan beberapa temuan terkait perubahan kepatuhan dalam budaya perkawinan Sorong serah adat suku Sasak di Kecamatan Selong adalah sebagai berikut :

1. Dalam aspek pendidikan

Terjadinya degradasi kepatuhan masyarakat dalam melaksanakan prosesi adat Sorong serah secara umum disebabkan oleh faktor determinan yang menyebabkan sebagian besar masyarakat di Kecamatan Selong tidak melakukan Sorong serah yaitu faktor kebahasaan. Masih banyak masyarakat yang menganggap bahwa adat Sorong serah bukanlah budaya asli suku Sasak. Mereka manyimpulkan ini karena bahasa yang digunakan oleh pembayun (juru bicara/ penyambung lidah) kedua belah pihak pada saat prosesi dalam acara Sorong serah yakni bahasa Jawa Kuno/ hanacaraka, sama dengan bahasa yang digunakan oleh masyarakat Hindu-Bali dalam proses persembahyangan mereka. Pada bagian berikutnya, penggunaan bahasa hanacaraka dalam proses Sorong serah menyebabkan masyarakat suku Sasak kekinian (modern) yang tidak pernah mempelajari/ menggunakan bahasa tersebut menjadi tidak paham apa yang terjadi dalam proses adat Sorong serah. Sehingga, secara perlahan masyarakat suku Sasak tidak secara penuh melaksanakan adat Sorong serah tesebut.

\section{Dalam aspek pengetahuan agama}

Dengan keberadaan dari lembaga pendidikan YPH PPD NW yang banyak tersebar hampir di seluruh wilayah kabupaten Lombok Timur memberikan banyak penanaman dan pembiasaan dalam masyarakat di Kecamatan Selong untuk kembali kepada ajaran yang di ajarkan dalam agama melalui proses pendidikannya.

Selain itu juga dalam masyarakat di kecamatan Selong terjadinya peringkasan prosesi perkawinan adat merariq sebagai sebuah manifestasi dari pemahaman atas interpretasi masyarakat terhadap apa yang mereka dapat selama menuntut ilmu agama. Dimana masyarakat di Kecamatan Selong kini hanya melaksanakan 3 ritual adat 
dalam perkawinan yaitu Besejati, beselabar dan bait janji dalam satu acara yang kemudian dilanjutkan dengan acara inti dari perkawinanya itu akad nikah, dan diakhiri dengan tradisi bejango. Sehingga dalam prakteknya prosesi adat Sorong serah mengalami perubahan dalam proses pelaksanaannya. Dimana masyarakat di kecamatan Selong kini sudah tidak lagi menjalankan adat Sorong serah.

3. Dalam aspek globalisasi

Terkait dengan arus dari bias globalisasi dalam membentuk perubahan kepatuhan terhadap budaya Sorong serah ialah yang pertama, adanya pemikiran masyarakat untuk lebih menyederhanakan delapan step proses adat merariq. Dimaklumi bahwa prosesi pernikahan baik dalam proses sebelum dan sesudah akad nikah membutuhkan kesibukan yang cukup banyak untuk semua keluarga, maka untuk mengurangi itu semua maka penyederhanaan proses merariq menjadi sebuah keniscayaan. Alasan lainnya yakni terkait dengan masalah ekonomi. Semakin panjang waktu dan proses merariq itu sendiri akan membutuhkan biaya yang banyak. Sehingga dalam kesehariannya dalam masyarakat di kecamatan selong kini lebih mengedepankan aspek praktis dan ekonomis dalam setiap sisi kehidupannya.

\section{DAFTAR RUJUKAN}

Azhar,Muhammad. 1987. "Kamus Bahasa Sastra Sasak Indonesia”. Mataram (Lombok) : PT. IntanPariwara.

DepartemenPendidikandan Kebudayaan. 1995. KamusUmumBahasa Indonesia, Jakarta: BalaiPustaka.

Kennedy, Paul. 1995. MenyiapkanDiriMenghadapi Abad $K e-21$, PenerjemahYayasanOborIndonesia (Maimoen S), Jakarta : YayasanObor Indonesia.

Martono, Nanang. 2011. SosiologiPerubahanSosial.Jakarta :RajawaliPers

Ohmae, Kenichi. 2002. Hancurnya Negara-Bangsa, Bangkitnya Negara KawasandanGeliatEkonomi Regional di DuniatakTerbatas, PenerjemahRuslani, Yogyakarta: Qalam

PayasanLalu. 2004. Proses AdatPerkawinanSasak "SorongserahAjiKrama". Mataram - NTB :Depdikbud.

Ritzer, George. 2004. Globalization of Nothing; Why So Many Make So Much 